\title{
RECENZJE
}

\section{Bojan Miljković, Čudotvorna ikona u Vizantiji, Vizantološki Institut Srpske akademije nauka i umetnosti, Beograd 2017, ss. 333.}

doi.org/10.14746/bp.2018.25.19

Ikona jako wizerunek zajmowała istotne, kluczowe miejsce w systemie aksjologicznym Bizantyńczyków. Stała się przyczyną jednego z najważniejszych konfliktów wewnętrznych w historii Bizancjum ${ }^{1}$. W 2017 r. otrzymaliśmy nową pracę dotyczącą świętych wizerunków w historii oraz kulturze państwa Romejów, szczególnie w kontekście wiary w moce cudotwórcze najsławniejszych bizantyńskich ikon. Książka będąca przedmiotem niniejszej recenzji jest rozszerzoną wersją rozprawy doktorskiej Bojana Miljkovicia o tym samym tytule, obronionej w 2012 r. na Wydziale Filozoficznym Uniwersytetu Belgradzkiego. Materiał zaprezentowany w monografii został zebrany i opracowany w wyniku prac nad porządkowaniem zbiorów ikon znajdujących się w monasterach Chilandar i Karies, które prowadzono w latach 2000 2008. Zainteresowania Autora publikacji to przede wszystkim historia i wyposażenie serbskiego monasteru w Studenicy², klasztorów na Atosie (Chilandar, Karies i Watopedia ${ }^{3}$ ), a także postaci św. Sawy w kontekście jego wkładu dla rozwoju sztuki prawosławnej ${ }^{4}$.

Książka została podzielona na trzy główne rozdziały. Pierwszy (o tytule Arché s. 23-52) dotyczy historii powstania kultu ikon, przedstawiając źródła hellenistyczne oraz religijne, które wpłynęły na ten fenomen. W kolejnym rozdziale (Dógma -

\footnotetext{
${ }^{1}$ Spór o ikony bywa wykorzystywany również współcześnie jako użyteczna metafora: A. Doda-Wyszyńska, Inwazja ikonoklastów. Filozofia przedstawienia Jacques'a Rancière'a, Poznań 2012, s. 43 51. Dyskusja teologiczna nad wykorzystaniem niektórych motywów artystycznych w wizerunkach kontynuowana jest do dziś: Z. Bator, Wspótczesna ikona Boga Ojca. Nowatorstwo czy herezja?, „Teologia w Polsce" 9/1, 2015, s. 97-108.

${ }^{2}$ Сликарство западног улаза у манастир Студенииу из 1208/9. године, [w:] Трећа југословенска конферениија византолога, Београд-Крушевац 2002, s. 183-188; La décoration peinte de l'entrée ouest de l'enceinte du monastère de Studenica - 1208/09, „Cahiers balkaniques” 3, 2000, p. 71-80.

${ }^{3}$ Српски панагијар из Ватопеда, „Зборник радова Византолошког института” 49, 2012, s. 355-364, Карейская Богородица Млекопитательница. Краткая история и первоначальный вид (Coauteur avec Юрий Бобров), „Хиландарски зборник” 12, 2008, s. 183-188; “Повест” о чудотворним иконама манастира Хиландара, „Зограф” 31, 2006/7, s. 219-228, Хиландарска икона српског цара Стефана, „Зборник радова Византолошког института” 43, 2006, s. 319-348.

4 Житија светог Саве као извори за историју средњовековне уметности, Београд 2008, ss. 265; La vie de saint Sava de Serbie par Domentijan et les cultes des icônes athonites thaumaturges de la Vierge, „Byzantion” 78, 2008, s. 304-338
} 
s. 53-86) Autor skupił się na materiale źródłowym pochodzącym z soboru nicejskiego w 787 r., zawierającym m.in. wiele przekazów o wizerunkach sprawiających „cuda”. Ostatni rozdział (Praksis - s. 87-283) to główna część zaprezentowanego wykładu, zawierająca kluczowe informacje na temat dziejów poszczególnych ikon bizantyńskich, dotyczące przede wszystkim przekazów o wierze w „cudowność” przedstawionych wizerunków. Warto zwrócić uwagę na bogatą warstwę ilustracyjną pracy (blisko 150 zdjęć ikon oraz materiału numizmatycznego i sfragistycznego). Jej mankamentem jest brak numerowania i spisu zaprezentowanych elementów graficznych. Dziwi to tym bardziej, że Autor pamiętał o rozwiniętych indeksach imion i nazw miejscowości (s. 307-333). Zaprezentowano również podstawową bibliografię tematu (s. 11-22).

W pierwszej części pracy Autor wychodzi ze słusznego założenia, że żeby dobrze zrozumieć fenomen bizantyńskiego kultu ikon należy uwzględnić wszystkie źródła cywilizacji powstałej nad Bosforem. Nie jest to wyłącznie tradycja judaistyczna oraz chrześcijańska (choć o niej również wspomina serbski badacz chociażby w kontekście przykazań Mojżeszowych, Ksiąg Powtórzonego Prawa i Kapłańskiej, postawy Ananiasza, Miszaela oraz Azariasza), ale również hellenistyczna i rzymska. Autor wspomniał tutaj liczne formy pogańskiego kultu posągów. Jak podkreślił w swojej pracy, oprócz proskynezy przed wizerunkami bóstw, ofiarami krwawymi i bezkrwawymi, paleniem kadzideł $\mathrm{i}$ lamp, istniały w kultach pogańskich także takie formy uwielbienia jak uroczyste procesje z posągami (ksóanon) - m. in. Dionizosa i Apollona w Atenach, Demeter w Hermium (Argolida), Artemidy w Sparcie, czy Zeusa-Amona w Egipcie. Ostatni z przykładów jest szczególnie interesujący w kontekście późniejszych wierzeń bizantyńskich - figura Zeusa-Amona miała poprzez ruchy swej głowy i inne znaki wyznaczać kierunek marszu procesji. Podobny rytuał występował również w Hierapolis (Manbidż), gdzie „poruszał się” posąg Apollona. Pojawiły się także pogańskie legendy o cudownym „ukazywaniu się" posągów lub o ich samodzielnym przemierzaniu ogromnych odległości (jak np. ksóanon bogini Ateny, który miał się objawić w mieście jej imienia po prostu bezpośrednio „,z nieba”, posąg Wielkiej Kybele, która samodzielnie miała przenieść się z Pesynuntu do Rzymu, a także wizerunek Apollona przebywający ogromne odległości ,pływając” samodzielnie po morzach). Kolejny istotny element jaki podnosi w swoim wykładzie Autor to fakt kopiowania posągów i przenoszenia tych wizerunków do kolejnych świątyń, jak również tworzenia mniejszych wersji figur traktowanych jak amulety (wśród przykładów wyróżnić możemy Sullę, całującego przed bitwą złotą statuetkę Apolla Pytyjskiego, którą nosił ze sobą na szyi).

Po tym wstępie Autor przeszedł do przykładów synkretyzmu religijnego obecnego w okresie rzymskim. Powołał się tutaj m.in. na zachowane zabytki Dura Europos, gdzie obok świątyń pogańskich funkcjonowały miejsca kultu chrześcijańskiego i judaistycznego. Wszystkie zdobione były figuralnie, w podobnym do siebie stylu. Przedstawienia te różnią się tematyką (właściwą dla każdej religii), ale nie stylem. Wspomniał również o przekazach dotyczących Aleksandra Sewera, który miał w swoich komnatach pałacowych specjalne miejsce przeznaczone do modlitw, gdzie oprócz zwyczajowych wyobrażeń znajdowały się też figury takich postaci jak Abraham czy 
Chrystus. W tym kontekście Autor nie zapomniał o posągu Chrystusa z Cezarei, czczonym również przez pogan, który został usunięty przez Juliana Apostatę (s. 31-34).

Po omówieniu najbardziej charakterystycznych przykładów kultu posągów oraz synkretyzmu religijnego, Autor przeszedł do przykładów zdobnictwa figuralnego w pierwszych wiekach chrześcijaństwa, m.in. w katakumbach. Dokonując przeglądu literatury patrystycznej wyszczególnił m.in. bliżej nieokreślone przedstawienia w kościele w Nazjanzie, które datować można na IV wiek, wspomnienie o obrazach (lub mozaikach) przedstawiających męczeństwo św. Teodora w kościele z jego relikwiami w Heraklei Pontyjskiej, a także wizerunki męczeństwa świętej w kaplicy św. Eufemii z Chalcedonu. Autor drobiazgowo gromadzi i analizuje wzmianki dotyczące wyposażenia kościołów w elementy dekoracyjne - poczynając od bizantyńskiej Italii aż po Antiochię i Aleksandrię (s. 34-39).

$\mathrm{Z}$ drugiej strony badacz przychylił się do tezy, iż ikonoklazm nie był nagłym, rewolucyjnym zjawiskiem, ale wynikającym z postaw reprezentowanych przez część duchownych praktycznie od samego początku istnienia chrześcijaństwa. Wśród autorów jednoznacznie wypowiadających krytyczne opinie o oddawaniu czci jakimkolwiek wizerunkom wymienił m.in. Klemensa Aleksandryjskiego, Orygenesa, Tertuliana, Euzebiusza z Cezarei ${ }^{5}$ oraz Epifaniusza z Salaminy ${ }^{6}$. Przypomniał również postanowienia synodu w Elwirze, którego kanon trzydziesty szósty zakazywał przedstawień wizerunkowych w kościołach (s. 39-44)7. Pierwszy rozdział kończy się omówieniem wczesnobizantyńskich apologii ikon, m.in. autorstwa Hypacjusza z Efezu ${ }^{8}$. Badacz zajął się pojawiającymi się w tym okresie (VI wiek) przekazami na temat wizerunków „nie uczynionych ludzką ręką”, spośród których za przykładowe uznał m.in. Mandylion z Edessy ${ }^{9}$ oraz obraz z Camuliana ${ }^{10}$. Oprócz wymienio-

${ }^{5}$ D. Budzanowska, Z historii preikonoklazmu. Euzebiusz z Cezarei i jego List do Konstancji (na tle epoki), „Warszawskie Studia Teologiczne” XXVI/1, 2013, s. 63-83.

${ }^{6}$ Ks. N. Widok, Udziat Epifaniusza z Salaminy $w$ walce z kultem obrazów, [w:] Święte wizerunki w przekazie Dobrej Nowiny, red. idem, Opole 2018, s. 9-36; O. Cyrek, Teologiczne argumenty przeciwników i zwolenników kultu ikon na podstawie niektórych pism Epifaniusza z Salaminy $i$ „Mowy” Jana Damasceńskiego dotyczącej kultu obrazów, „Resovia Sacra. Studia Teologiczno-Filozoficzne Diecezji Rzeszowskiej” 16, 2009, s. 103-114; Epifaniusz z Salaminy, Pisma przeciw obrazom, przekł. M. M. Dylewska, „Vox Patrum” 2002, t. 42-43, s. 551-565.

${ }^{7}$ Więcej na temat stosunku kościoła do wyobrażeń figuralnych w okresie wczesnochrześcijańskim zob. m.in.: ks. M. Kieling, Kościól wobec idolatrii na podstawie Dokumentów Synodów w latach 50-381, „Vox Patrum” 30, t. 55, 2010, s. 275-292.

${ }^{8}$ Znanymi polskiemu Czytelnikowi doskonale dzięki: Hypatiusz z Efezu, O kulcie obrazów (Symmikta dzetemata I 5), z języka greckiego przełożył, wstępem i komentarzem opatrzył ks. J. Naumowicz, ,Vox Patrum” 11-12 (1991-1992), z. 20-23, s. 429-435.

${ }^{9} \mathrm{Na}$ temat tego wizerunku w polskiej literaturze bizantynologicznej: M. Tycner-Wolicka, Opowieść o wizerunku z Edessy. Cesarz Konstantyn Porfirogeneta i nieuczyniony ręka wizerunek Chrystusa, Kraków 2009, ss. 232.

${ }^{10}$ Autor nie odwołuje się tutaj jednak do powszechnie znanej i dostępnej na ten temat literatury: C. Mango, The Camuliana Image of Christ, [in:] Art of the Byzantine Empire 312-1453. Sources and Documents, Toronto 1986, s. 114-115. 
nych wyżej przedstawień Autor zajął się analizą dwóch tekstów polemicznych (wobec pogan i Żydów), Jana III, biskupa Tessaloniki oraz Leoncjusza, biskupa Néapolis. Szczególnie drugi z nich uznał badacz za dowód rozprzestrzeniania się wiary w nadprzyrodzoną moc obrazów już w I połowie VII wieku, ponieważ wzmiankowane w nim zostały po raz pierwszy wizerunki, które obdarzone miały być mocami wypędzania demonów oraz leczenia niektórych chorób ${ }^{11}$. W narracji Autora pojawił się w tym miejscu kontekst oskarżania w literaturze bizantyńskiej Żydów o wywołanie ikonoklazmu. Warto w tym miejscu zaznaczyć wątpliwą wiarygodność tych przekazów, szczególnie w przypadku edyktu ikonoklastycznego, którego autorem miał być Jazyd II. Abstrahując od faktu, że edykt ten nie wprowadzał ikonoklazmu jako oficjalnej doktryny kalifatu ${ }^{12}$, a był jedynie elementem prześladowań chrześcijan pozostających pod władzą muzułmańską należy zaznaczyć, że wprowadzenie wątku żydowskiego do narracji na ten temat obarczone jest pewnym założeniem propagandowym ${ }^{13}$. Na zakończenie warto zauważyć, że pomimo przedstawienia bogatego materiału źródłowego Autor nie pokusił się o zaprezentowanie jakiejkolwiek typologii

${ }^{11}$ Zdecydowanie głębszą analizę tej problematyki niż w prezentowanej książce znajdzie Czytelnik w polskim artykule: ks. J. Naumowicz. Leoncjusz z Neapolis i jego apologia chrześcijańskich obrazów. „Warszawskie Studia Teologiczne”. 7, 1994, s. 89-102. W kontekście wizerunków „przynoszących ukojenie" i archeologicznych znaleziskach związanych z tematem warto wspomnieć: M. Szada, Funkcje wizerunków na wczesnochrześcijańskich dewocjonaliach pielgrzymich - pomiędzy świętym obrazem a relikwia, [w:] $\Sigma X O \Lambda H$. Centrum - Peryferia - Granice, red. S. Banasiak, P. Gumiela, J. Kłos, M. Szada, współpraca Z. Fiołna, E. Kondracka, Warszawa 2012, s. 99-105.

${ }^{12}$ Część autorów słusznie zauważa, że ikonoklazm islamski nie został formalnie wprowadzony, na pewno zaś miał zupełnie inny charakter niż ikonoklazm bizantyński: ks. M. Sadowski, Muzułmańska awersja do sztuki figuratywnej a bizantyjski ikonoklazm. Krótka charakterystyka problemu, „Teologia i Człowiek. Kwartalnik Wydziału Teologicznego UMK” 27 (3), 2014, s. 189-203. W kontekście duchowym zaś nieformalny zakaz czczenia wyobrażeń znalazł swoje uzupełnienie poprzez inne praktyki kultowe: M. Micherdziński, Zbawczy wymiar teokalii w Koranie a ikonoklazm islamu, „Analecta Cracoviensia” 46, 2014, s. 83-103.

13 Teofanes we fragmentach dotyczących edyktu ikonoklastycznego Jazyda II czyni centralną postacią cesarza Leona III. Widoczne jest to, gdy potraktujemy jego relację w latach 6213-6215 jako pewną całość, zawierającą ciąg logicznie po sobie postępujących wydarzeń: przymusowy chrzest Żydów wywołujący wśród nich nastroje antybizantyńskie, powstanie żydowskiego ruchu mesjanistycznego skierowanego m.in. przeciwko świętym wizerunkom, zbliżenie się jednego z członków ruchu do kalifa Jazyda, wydanie edyktu jako efekt wpływu żydowskiej sekty mesjanistycznej, powrót przesiąkniętego ideami ikonoklastycznymi Besera do Konstantynopola i przekonanie Leona do przyjęcia obrazoburczych przekonań. Relację spina klamra tematyczna dotycząca błędów Leona. Opisana przez Teofanesa szybka śmierć Jazyda II tuż po wydaniu edyktu, choć nie wydaje się zgoda z przekazami innych źródeł (przede wszystkim armeńskich i egipskich) to jednakowoż może mieć wymiar moralizatorski - autor "Chronografii” przestrzegał w ten sposób władców przed mieszaniem się w sprawy doktryny wiary: B. Cecota, Edykt ikonoklastyczny Jazyda II w świetle „Chronografii” (AM 6215) Teofanesa Wyznawcy, „Byzantinoslovaca” 3, 2010, s. 37-46. Postawa Teofanesa wydaje się być koherentną z ideą pentarchii formułowaną przez teologów broniących kultu ikon, wśród których dominującą pozycję uzyskał pogląd podważający możliwość cesarskiego wpływu na rozwój dogmatów i reguł kościelnych, zob.: O. Kashchuk, Idea pentarchii jako rękojmia jedności kościoła w dobie ikonoklazmu. Stanowisko Teodora Studyty, „Vox Patrum” 32 (2012), s. $201-220$. 
przekazów dotyczących obrazów w okresie wczesnochrześcijańskim, a chociażby dotychczasowych badań na ten temat ${ }^{14}$.

W drugim rozdziale pt. Dógma Bojan Miljković skupił się przede wszystkim na analizie aktów II soboru nicejskiego, traktując je jako istotne źródło dla poznania historii powstania kultu ikon w kontekście „czynienia” cudów. Badacz przedstawił pokrótce chronologię synodu, przede wszystkim jednak omówił pojawiające się w aktach soborowych relacje o uzdrowieniach za przyczyną ikon, wypędzeniach demonów, a także te o nieudanych próbach usuwania świętych obrazów przez ikonoklastów (s. 55). Autor dokonał selekcji interesującego materiału: o karach spotykających muzułmanów za złe traktowanie ikon, obrazach, które uzdrawiały od zarazy lub chorób, piciu wody z fragmentami ikon czy usunięciu bólu zęba lub głowy po przyłożeniu do danego miejsca cudownego obrazu.. Wspomniane zostały również przypadki, kiedy ikona „wymogła” określonymi działaniami o nadprzyrodzonym charakterze oddanie jej czci, czy też nawracała tych, którzy popadli w herezję lub grzech cudzołóstwa (s. 61-62). Zgodnie z przedstawionymi w książce relacjami ikony wypełniały studnie wodą, lampy przed ikonami nie przestawały płonąć mimo braku oliwy, a sama oliwa okazywała się doskonałym lekarstwem. Dzięki działaniu cudownej mirry pochodzącej z ikon chromi zaczynali chodzić, a niewidomi odzyskiwali wzrok. Co ważne, cuda te spotykały nie tylko chrześcijan, ale również niewierzących, np. Żydów (s. 64-65). Nieco miejsca poświęcił Autor głównym obrońcom kultu ikon. Jednakże ten krótki podrozdział zdominowany został przede wszystkim przez przedstawienie głównych myśli Jana z Damaszku ${ }^{15}$. Badacz starał się wyszczególnić te fragmenty z dzieł teologa, w których wspominał on o zdolności czynienia cudów przez święte wizerunki (s. 66-72). W kolejnym podrozdziale Bojan Miljković opisał okoliczności, które doprowadziły do odnowienia ikonoklazmu w początkach IX wieku, wspominając m.in. o wygnaniu Teodora Studyty i Nicefora Patriarchy ${ }^{16}$. Wymieniając różnorodne ikonoklastyczne zakazy zwrócił uwagę na fakt, iż stanowią one ciekawe źródło dla poznania form kultowych towarzyszących adoracji świę-

${ }^{14}$ Zainteresowanym tym zagadnieniem Czytelnikom warto polecić chociażby: ks. M. Janocha, Stowo a obraz: źródta literackie do dziejów estetyki i sztuki bizantyńskiej, „Series Byzantina” 2, 2004, s. $21-41$.

${ }^{15}$ Niemniej jednak znacznie więcej informacji na ten temat można znaleźć w polskich opracowaniach, m.in.: P. Feliga, Obrona kultu obrazów w ,Trzech mowach apologetycznych przeciwko tym, którzy odrzucaja święte obrazy” św. Jana Damasceńskiego, „Collectanea Theologica” 87 (3), 2017, s. 25-66; M. Pyc, Chrystologiczna argumentacja w ,Mowach obronnych przeciw tym, którzy odrzucaja święte obrazy” Jana Damasceńskiego, „Poznańskie Studia Teologiczne” 25, 2011, s. 159-171.

${ }^{16}$ Niezrozumiałe wydaje się, dlaczego Autor zdecydował się opisać dość dokładnie początki drugiego ikonoklazmu, skoro we wcześniejszej części pracy pominął kwestie związane z powstaniem pierwszej kontrowersji obrazoburczej. Temat jest przecież dość dobrze opisany, kilka reasumpcji dokonano również w literaturze polskiej: M. Pyc, Ikonoklazm i jego argumentacja przeciwko kulturowi obrazów w ostatnim z chrystologicznych sporów chrześcijańskiej starożytności, „Colloquia Theologica Ottoniana”, 1, 2012, s. 23-36; M. Chudzikowska-Wołoszyn, Początki sporów ikonoklastycznych w Bizancjum, „Studia Elbląskie" 7, 2006, s. 79-89. 
tych wizerunków przez ikonodulów, m. in. palenie kadzideł przed ikonami, śpiewanie przed nimi hymnów, wybieranie ikon na chrzestnych dzieci, mieszanie cząstek ikon $\mathrm{z}$ winem i chlebem podczas ceremonii najświętszego sakramentu, zastępowanie ikonami ołtarza podczas liturgii (s. 72-86). W podsumowaniu rozdziału Autor formułuje kilka wniosków dotyczących rozwoju kultu ikon w cesarstwie, m.in. sugeruje, że wiara w cudowną moc wizerunku powstała w II połowie VI wieku, a zjawisko to związane było przede wszystkim z destabilizacją sytuacji społeczno-politycznej cesarstwa, podziałami religijnymi w łonie kościoła wschodniego, a także licznymi zagrożeniami zewnętrznymi państwa.

Ostatni rozdział pt. Praksis otwiera wstęp dotyczący przywracania kultu ikon odnalezionych po okresie ikonoklazmu lub sprowadzonych do cesarstwa po udanych kampaniach wojennych na wschodzie w drugiej połowie X wieku (s. 87-117). Wśród przykładów takich wizerunków Autor omówił m.in. prawdopodobną kopię obrazu Teotokos z Jerozolimy, która pojawiła się w konstantynopolitańskiej Hagia Sophia za sprawą Leona Mądrego, czy ikonę wywiezioną z Bejrutu w 975 r. przez wojska Jana Tzimiskesa (s. 87-95). Na kolejnych stronach serbski badacz przedstawił "cudowne” wydarzenia związane z „objawieniem” ikony z jeziora Gazourou, nietkniętych trzęsieniem ziemi wizerunkach ze świątyni Teotokos Pege, czy cudownych odnalezieniach ikon w kościołach w Blachernach w Konstantynopolu oraz Latomou w Tessalonice (s. 96-117). Autor uważa również, że właśnie w omawianym okresie kult ikon został w pełni przyjęty na dworach bizantyńskich cesarzy. Na potwierdzenie swojej hipotezy wymienił m.in. przykład z tryumfu Jana Tzimiskesa, podczas którego oddał on przeznaczone sobie miejsce świętemu wizerunkowi, zachowanie Bazylego II, który wyszedł naprzeciw wojsk Bardasa Fokasa ,uzbrojony” w ikonę zamiast tarczy, czy wzmianki Michała Psellosa o zwyczaju noszenia ikon przed wojskiem podczas wypraw wojennych (s. 104-106).

Po wstępie następuje metodyczne omówienie najsłynniejszych bizantyńskich wizerunków, którym przydawano moc nadprzyrodzoną. Jako pierwsza wspomniana została ikona Chrystusa Antiphonitis. Autor opisał długą historię wizerunku, sięgającą czasów Herakliusza oraz legendy o pożyczce udzielonej przed ikoną, która była traktowana jako uczestnik transakcji oraz wierzyciel. Wspomniał o szczególnej atencji, jaką wiązała z ikoną cesarzowa Zoe (1028-1050) oraz o wierze w przepowiadanie przez obraz przyszłości (w przypadku dobrych wydarzeń miał się mienić szczególnym blaskiem). Badacz zwrócił uwagę na zagadnienie rozprzestrzeniania się kultu na inne regiony cesarstwa, m.in. odnalazł jego ślady w Sparcie na Peloponezie, w Efezie i Tessalonice oraz na Cyprze. Bojan Miljković nie ograniczył się jedynie do źródeł pisanych, ale przeanalizował również materiał numizmatyczny, np. monety cesarzowej Zoe z ww. wizerunkiem (s. 117-129).

W kolejnym podrozdziale omówione zostały wzmianki dotyczące wizerunku Matki Bożej Blacherneńskiej (Blacherniotissa): o „samodzielnym” unoszeniu się zasłon w kościele w Blachernach, ,znakach” skierowanych do cesarza Aleksego by nie wyruszał na wyprawę przeciwko Normanom, wykorzystaniu wizerunku przez Romana 
Diogenesa podczas ekspedycji wojennych. Autor nie zapomniał o pieczęciach i monetach, gdzie Orantka została przedstawiona m.in. na numizmatach Konstantyna Monomacha, czy Michała VI Stratiotikosa. Serbski badacz przedstawił również krótkie omówienie historii kopii ikony znajdujących się w innych ośrodkach bizantyńskich, na Rusi, a także na zachodzie (s. 129-146). Wizerunek Chrystusa na Chalke opisany został przede wszystkim w kontekście domniemanego cudu uzdrowienia cesarza Aleksego poprzez katapetazmę (zasłonę) wizerunku, co miało przyczynić się do budowania kultu obrazu wśród przedstawicieli dynastii Komnenów, a następnie być kontynuowane w ramach cesarstwa nicejskiego oraz władców z dynastii Paleologów (s. 146-158).

Na stronach 158-167 Autor przedstawił różnorodne wizerunki (z wykorzystaniem materiału sfragistycznego) tessalonickiej Teotokos Hagiosoritissa, by następnie przejść do najbardziej znanego przedstawienia bizantyńskiego - Hodigitrii (s. 168209). W podrozdziale Bojan Miljković zaprezentował m.in. domniemania dotyczące pochodzenia wizerunku związane z Ziemią Świętą oraz Synajem, a także dzieje kopii, które możemy odnaleźć w Rosji, krajach bałkańskich, jak również na zachodzie. Następnie przeszedł do historii wizerunku w klasztorze Hodigon, przypisywanych temu miejscu wydarzeniach nadprzyrodzonych, a także tradycji procesji z ikoną i towarzyszącym tej formie czci „cudom”. Znajdziemy tutaj również wiele informacji na temat kultu jakim obdarzyli wizerunek przedstawiciele dynastii Komnenów i Angelosów, m. in. wykorzystania obrazu podczas oblężenia Konstantynopola w 1187 r., a także znaczeniu jakie ikonie nadali Paleologowie, łącząc kult z podziękowaniami za zachowanie Miasta w trudnych dla niego momentach. Dla przykładu Andronik II odbył procesję w podziękowaniu za pokonanie uzurpatora, zaś Andronik III za zwycięstwo nad Turkami. Przed ikoną jako świadkiem składano również przysięgi zaprzestania działań wojennych podczas wojen domowych w XIV wieku. Nic dziwnego, że kult kontynuowano aż do ostatecznego upadku Konstantynopola. Według niektórych relacji wizerunek miał przepowiedzieć to wydarzenie - podczas ostatniej tradycyjnej procesji wtorkowej ulicami miasta w dniu 27 maja 1453 r. ikona „nie chciała” ruszyć z miejsca, a następnie podczas peregrynacji doszło do silnego załamania pogody, tak że potoki wody omal nie porwały uczestników uroczystości.

W kolejnym podrozdziale Autor przybliża Czytelnikom ikonę Teotoks Kyriotissa, zarówno w wymiarze kultu osobistego (np. modlitw matki Michała Psellosa w intencji syna), a także wydarzeń o randze państwowej (np. „,znaków” zapowiadających klęskę pod Myriokefalon w 1176 r.). Nie brakuje informacji na temat samego wizerunku, który znajdował się w kościele obecnie funkcjonującym jako meczet Kalenderhane (s. 210-218). Po przedstawieniu najbardziej znanych ikon cesarstwa, serbski badacz dokonał opisu pozostałych, już nie tak słynnych wizerunków Matki Bożej i Chrystusa funkcjonujących w Konstantynopolu, jak i w innych miastach bizantyńskich, m.in. Teotokos Anthiniotissa z Aten, czy św. Teodora z Amasei w Koryncie (s. 218-237).

Zakończeniem rozważań na temat świętych wizerunków wydają się być podrozdziały dotyczące kontynuacji kultu w Cesarstwie Łacińskim(s. 238-250), a także w pań- 
stwach pozostających bizantyńskimi już po ostatecznym upadku Konstantynopola w Cesarstwie Trapezuntu i Despotacie Morei (s. 250-256). Szczególnie godne polecenia są uwagi na temat obrazu Matki Bożej w świątyni Chrysokefalos, który został otoczony szczególnym kultem z polecenia Andronika I Gidosa, kiedy to udało się mu pokonać Seldżuków pod Trapezuntem w 1223 r., a także wizerunku czczonego przez Aleksego III Komnena w klasztorze Sumela.

Za podsumowanie pracy należy uznać podrozdziały, w których Autor opisał różnego rodzaju określenia, epitety stosowane wobec świętych wizerunków (s. 257283). Warto przytoczyć w tym miejscu interesujące ustalenia w tym zakresie. Bojan Miljković zasugerował np., że wszelkie tzw. epitety poetyczne, przydające danemu wizerunkowi cechy (łaskawy, miłosierny, itd.) występują praktycznie w każdym miejscu, gdzie czczona była jakaś poszczególna ikona. Nie są one absolutnie związane z konkretnymi wizerunkami lub miejscami. Na podstawie materiału toponimicznego natomiast możemy stwierdzić jak wiele bizantyńskich miast miało swoje opiekuńcze ikony (m.in. Ateny, Abydos, Trajanopolis), a także ukazać zasięg rozwoju kultu ikon lokalnych świętych m.in. w Grecji właściwej, na Bałkanach i Cyprze, czy w południowej części Azji Mniejszej.

Pracę Bojana Miljkovicia należy uznać za interesującą próbę podjęcia tematu, jednakże obszerność podjętych zagadnień nie pozwoliła Autorowi na uniknięcie wielu uogólnień. Dość zaskakująca jest również konstrukcja pracy. Pierwsze dwa rozdziały mają charakter wyłącznie szkiców wprowadzających, natomiast ostatni zdecydowanie dominuje nad pozostałą częścią książki. Być może szkieletowość dwóch pierwszych części wynika z założeń związanych z wymaganiami wydawniczymi, jednakże nie zostało to zaznaczone w żadnym miejscu omawianego tekstu. Brakuje również odpowiedniego wprowadzenia w tematykę trzeciego rozdziału, choćby wstępu metodologicznego, prezentującego dokonania nauki w zakresie typologii wizerunków ikon bizantyńskich ${ }^{17}$. Warto też wspomnieć o dość ograniczonej bibliografii pracy, szczególnie przy tak szeroko założonym temacie prezentowanego studium, w której nie uwzględniono wielu nowych publikacji z zakresu historii sztuki bizantyńskiej ${ }^{18}$.

\section{Błażej Cecota}

\footnotetext{
${ }^{17} \mathrm{Na}$ ten temat podstawowe uwagi znajdzie Czytenik m.in. w: O. Cyrek, Frontalne i calopostaciowe wizerunki Chrystusa na ikonach bizantyńskich i ruskich. Schemat ikonograficzny, „Polonia Sacra” 16, 2012, s. 113-134; idem, Nowożytne ikony bizantyjskie i ruskie z symbolicznymi wizerunkami Jezusa Chrystusa. Kanon ikonograficzny i wyjaśnienie teologiczne, „Tarnowskie Studia Teologiczne” 31/1, 2012, s. 21-45; ks. H. Paprocki, Zwiazki pomiędzy ikona, teologia i liturgia, „Elpis” 13 (23-24), 2011, s. 39-58; ks. M. Janocha, Ruskie i rosyjskie ikony Hodegetrii, „Salvatoris Mater” 10/1, 2008, s. 153-172.

${ }^{18}$ Omówienia niektórych z nich znajdzie Czytelnik np. w: P. Waszak, W kręgu dyskusji o sztuce bizantyjskiej, „Klio. Czasopismo poświęcone dziejom Polski i powszechnym” 37/2, 2016, s. 141-154.
} 